\title{
THE BINDING OF CATIONS BY CHONDROITIN SULFATE
}

\author{
By SAUL J. FARBER 1 AND MAXWELL SCHUBERT 2 WITH THE TECHNICAL ASSISTANCE \\ OF NANCY SCHUSTER
}

(From the Departments of Medicine and Chemistry, and the Study Group on Rheumatic Diseases, New York University College of Medicine, New York, N. Y.)

(Submitted for publication June 27, 1957; accepted August 13, 1957)

The polyelectrolyte nature of chondroitin sulfate and related polysaccharides suggests they may bind cations. Since chondroitin sulfate is an extracellular component of mammalian connective tissue, the binding properties of this polyelectrolyte for cations may be of significance in the distribution and storage of extracellular cations. In disease states in which sodium is known to play a major role its storage and distribution may be altered as a result of changes in extracellular polysaccharide metabolism. The purpose of the present study is to determine the binding properties of chondroitin sulfate polyanions for the cations sodium, potassium, and calcium. The results indicate that sodium and potassium are bound to chondroitin sulfate to about the same extent, and that binding of calcium is somewhat greater.

Chondroitin sulfate is a salt with a molecular weight of about 20,000 to 30,000 (1), which is often isolated with sodium or potassium as its cation. It is a polymer consisting of about 50 repeating units of the kind represented in Figure 1 (2). If sodium chondroitin sulfate were completely ionized, the resulting polyanion could carry a total negative charge of 100 units per molecule. In the dry neutral salt this charge is balanced by 100 equivalents of cation such as sodium or potassium. Such cations are called counterions. During the past few years, study of several different types of synthetic polyelectrolyte salts has suggested that their ionization in solution is in effect not complete and that part of the total number of counterions may be bound to the polyion (3-9).

1 Supported (in part) by research grant H-1270 from the National Heart Institute, United States Public Health Service, and (in part) by the Life Insurance Medical Research Fund. Established Investigator, American Heart Association.

2 Supported by research grant A-28 (C) from the National Institute of Arthritis and Metabolic Diseases, United States Public Health Service.

\section{EXPERIMENTAL}

Chondroitin sulfate, isolated from beef nasal cartilage, was prepared as the crystalline calcium salt by methods previously described (10). This calcium salt was converted to the sodium or potassium salt by the use of the sodium or potassium form of Dowex-50. Chondromucoprotein as the potassium salt and desulfated chondroitin sulfate as the methyl ester were prepared by methods described elsewhere $(11,12)$. For convenience these substances will be referred to as $\mathrm{Na}_{2} \mathrm{ChS}, \mathrm{K}_{2} \mathrm{ChS}$, or $\mathrm{CaChS}$ for the chondroitin sulfate salts, $\mathrm{K}_{2} \mathrm{CMP}$ for the chondromucoprotein salt, and $\mathrm{MeCh}$ for the methyl ester of desulfated chondroitin sulfate. Polyion concentrations are given as period weights per liter. In each case these weights are the weight of the dry substance that on hydrolysis yields one gram molecular weight of galactosamine. Analytical data are given where the preparations are described (10-12).

Chondroitin sulfate as its sodium, potassium, or calcium salt was dissolved in distilled water to a concentration of $5 \mathrm{mg}$. per ml. Such solutions in amounts of $5 \mathrm{ml}$. were pipetted into cellophane bags which had previously been washed in distilled water. A few experiments were set up with the chondroitin sulfate at lower concentrations. Solutions of $\mathrm{K}_{2} \mathrm{CMP}$ were transferred by weight rather than by volume because of the high viscosity of the solutions in water in the absence of added salt. The cellophane bags were tightly double-knotted at each end and placed in glass vials. To each vial was added 10 $\mathrm{ml}$. of a solution of the corresponding sodium, potassium, or calcium chloride at a concentration in the range 1 to $140 \mu$ Eq. per $\mathrm{ml}$. On any given day each concentration of chondroitin sulfate salt with each of the concentrations of its corresponding chloride were run in duplicate. The vials were tightly stoppered with screw caps and placed in a slow rocker or in a revolving wheel for gentle agitation at $4^{\circ} \mathrm{C}$. for 24 hours; a few experiments were run for 48 to 96 hours.

The volume of each solution was measured and the solution analyzed for the appropriate cation and chloride. Values of $\mathrm{pH}$ were always between six and seven, and no appreciable difference was found between the inside and outside solutions. Sodium and potassium were determined by an internal standard flame photometer. Calcium was determined by titration with ferrous ammonium sulfate after precipitation with oxalate and oxidation by ammonium tetranitratocerate (13). Chloride determinations were carried out by potentiometric titration with silver nitrate (14). 


\section{SODIUM CHONDROITN SULFATE}

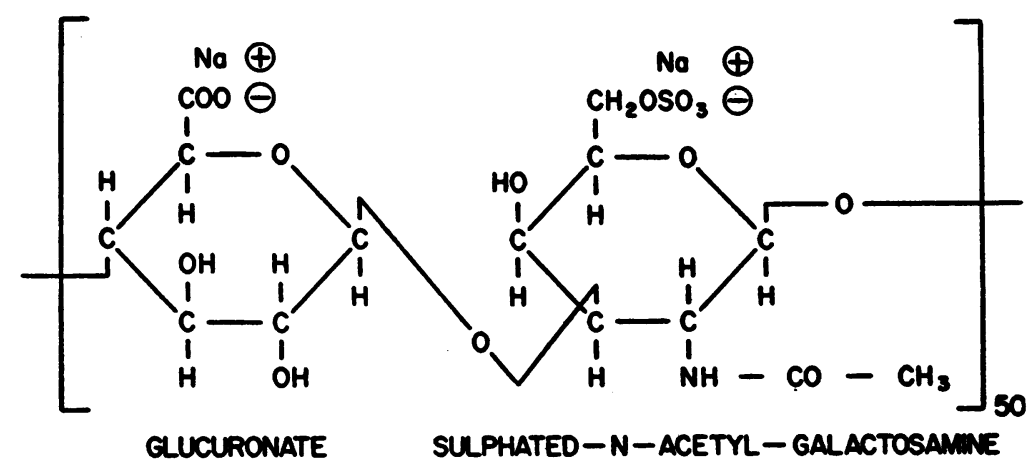

METHYL CHONDROITIN

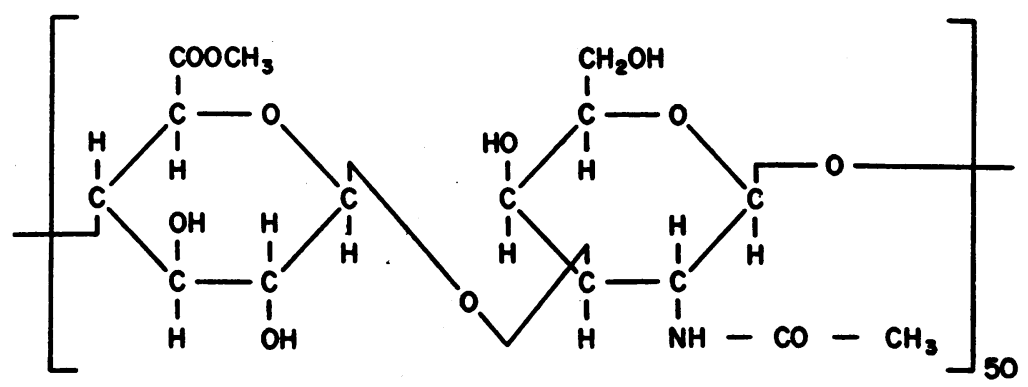

Fig. 1. Structure of the Repeating Units of Chondroitin Sulfate and Methyl Chondrortin

TABLE I

Values of sodium and chloride ion concentrations inside and outside the bag after equilibration for the indicated hours at $5^{\circ} \mathrm{C}$.*

\begin{tabular}{|c|c|c|c|c|c|}
\hline $\begin{array}{c}\text { Dialysis } \\
\text { time }\end{array}$ & $\begin{array}{c}\text { Nat+ } \\
\text { outside }\end{array}$ & $\begin{array}{c}\mathrm{Cl}^{-} \\
\text {outside }\end{array}$ & $\underset{\text { inside }}{\text { Nat }}$ & $\underset{\text { inside }}{\mathrm{Cl}^{-}}$ & $\mathrm{Na}+\mathrm{i}-\mathrm{Cl}-\mathrm{i}$ \\
\hline $\begin{array}{c}\text { hours } \\
24\end{array}$ & $\begin{array}{c}\mu E q . / \mathrm{ml} . \\
40.0 \\
40.1 \\
41.8 \\
41.3 \\
39.7 \\
39.7 \\
42.2 \\
41.5 \\
40.2\end{array}$ & $\begin{array}{c}\mu E q . / m l . \\
40.5 \\
40.3 \\
41.2 \\
41.2 \\
41.7 \\
41.5 \\
40.6 \\
41.3 \\
41.0\end{array}$ & $\begin{array}{c}\boldsymbol{\mu E q .} / \mathrm{ml} . \\
\mathbf{5 6 . 4} \\
\mathbf{5 6 . 4} \\
\mathbf{5 4 . 0} \\
53.0 \\
\mathbf{5 4 . 1} \\
\mathbf{5 3 . 7} \\
\mathbf{5 3 . 1} \\
\mathbf{5 4 . 0} \\
\mathbf{5 3 . 8}\end{array}$ & $\begin{array}{c}\mu E_{q} . / m h . \\
36.9 \\
36.9 \\
36.3 \\
36.6 \\
36.8 \\
37.1 \\
35.6 \\
36.9 \\
36.6\end{array}$ & $\begin{array}{c}\text { MEQ./ml. } \\
19.5 \\
19.5 \\
17.7 \\
16.4 \\
17.3 \\
16.6 \\
17.5 \\
17.1 \\
17.2\end{array}$ \\
\hline 48 & $\begin{array}{l}41.2 \\
41.8 \\
40.4 \\
41.2\end{array}$ & $\begin{array}{l}41.0 \\
41.0 \\
41.0 \\
41.2\end{array}$ & $\begin{array}{l}53.9 \\
53.5 \\
52.8 \\
53.2\end{array}$ & $\begin{array}{l}35.9 \\
35.9 \\
36.6 \\
36.6\end{array}$ & $\begin{array}{l}18.0 \\
17.6 \\
16.2 \\
16.6\end{array}$ \\
\hline 72 & $\begin{array}{l}40.7 \\
41.2\end{array}$ & $\begin{array}{l}40.6 \\
41.6\end{array}$ & $\begin{array}{l}54.7 \\
51.8\end{array}$ & $\begin{array}{l}36.6 \\
37.5\end{array}$ & $\begin{array}{l}18.1 \\
14.3\end{array}$ \\
\hline 96 & $\begin{array}{l}40.6 \\
40.3\end{array}$ & $\begin{array}{l}41.0 \\
40.5\end{array}$ & $\begin{array}{l}52.8 \\
53.6\end{array}$ & $\begin{array}{l}37.2 \\
36.5\end{array}$ & $\begin{array}{l}15.6 \\
17.1\end{array}$ \\
\hline
\end{tabular}

* Initial conditions: Inside the bag, $25 \mathrm{mg} . \mathrm{Na}_{2} \mathrm{ChS}$ in $5 \mathrm{ml}$. $\mathrm{H}_{2} \mathrm{O}$ (8.7 $\mu$ periods per $\mathrm{ml}$.); outside the bag, $10 \mathrm{ml}$. $0.06 \mathrm{M} \mathrm{NaCl}$.
RESULTS

Table I gives a sample of the experimental results for sodium chondroitin sulfate dialyzed against an initial sodium chloride concentration outside the bag of $0.06 \mathrm{M}$. The last column, the difference between the sodium and chloride ion concentrations inside the bag at equilibrium, averages $17.2 \mu \mathrm{Eq}$. per $\mathrm{ml}$. and serves as a check since this should be twice the chondroitin sulfate concentration inside the bag, which is 8.7 pperiods $\mathrm{Na}_{2} \mathrm{ChS}$ per $\mathrm{ml}$. Another check is the difference between the values of the sodium and chloride ion concentrations outside the bag, which should be zero. The greatest difference found (Line 5) amounts to 5 per cent of the values measured. Table I also shows that equilibrium is reached in 24 hours and is stable up to 96 hours.

Instead of presenting all of the measurements in detail as in Table I, the data are summarized in Tables II, III, and IV by averaging sets of experiments such as those of Table I. In Table II are the results of experiments with sodium chon- 
TABLE II

Mean values for ion concentrations inside and outside the bag at several concentrations of sodium chloride and of sodium chondroitin sulfate (period weight 576)

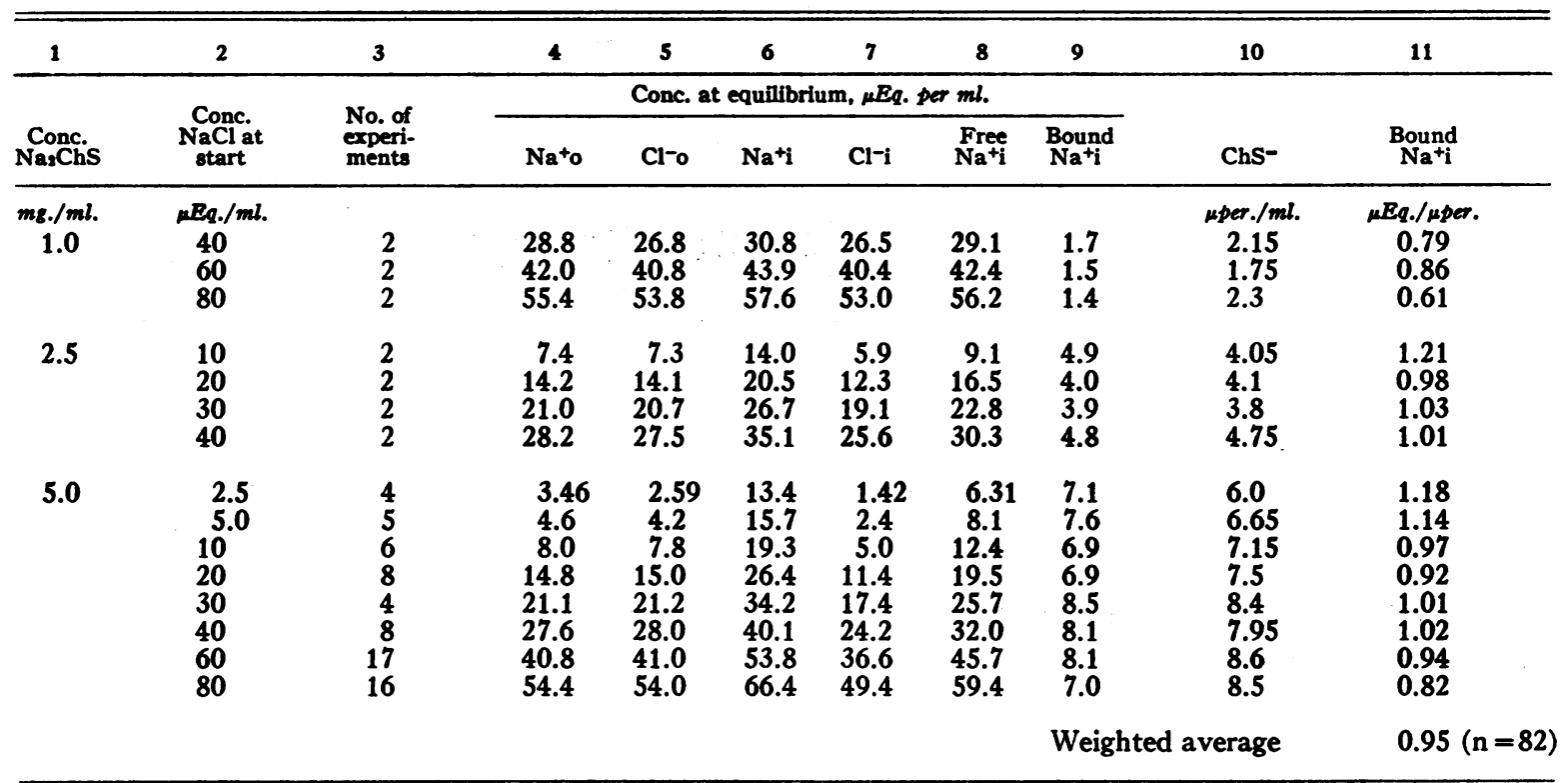

droitin sulfate at the three concentrations given in Column I. In Column 2 are the concentrations of $\mathrm{NaCl}$ outside the bag at the start of each experiment. Columns 4, 5, 6, and 7 give the experimentally determined values at equilibrium of the sodium and the chloride outside and inside the bag. In all cases the product of the sodium and chloride concentrations inside the bag is greater than the product of their concentrations outside the bag. Assuming this discrepancy to be due to binding of cation by the chondroitin sulfate anion and that the Donnan equilibrium holds approximately for concentrations instead of ion activities, the data of Columns 4, 5, 6, and 7 can be used to

TABLE III

Mean values for ion concentrations inside and outside the bag at several concentrations of potassium chloride and potassium chondroitin sulfate (period weight 608)

\begin{tabular}{|c|c|c|c|c|c|c|c|c|c|c|}
\hline 1 & 2 & 3 & 4 & 5 & 6 & 7 & 8 & 9 & 10 & 11 \\
\hline \multirow[b]{2}{*}{$\underset{\mathbf{K}_{3} \text { Conc. }}{\text { Cons }}$} & \multirow{2}{*}{$\underset{\text { start }}{\text { Conc. }}$} & \multirow[b]{2}{*}{$\begin{array}{l}\text { No. of } \\
\text { experi- } \\
\text { ments }\end{array}$} & \multicolumn{6}{|c|}{ Conc. at equilibrium, $\mu E q$. per ml. } & \multirow[b]{2}{*}{ ChS- } & \multirow[b]{2}{*}{$\underset{\mathbf{K}^{+} \mathbf{i}}{\text { Boound }}$} \\
\hline & & & $\mathbf{K}^{+} \mathbf{O}$ & $\mathrm{Cl}^{-} \mathrm{O}$ & $\mathbf{K}+\mathbf{i}$ & $\mathbf{C l}-\mathbf{i}$ & $\begin{array}{c}\text { Free } \\
\mathbf{K}^{+} \mathbf{i}\end{array}$ & $\underset{\mathbf{K}^{+} \mathbf{i}}{\text { Bound }}$ & & \\
\hline $\begin{array}{c}\text { mg./ml. } \\
2.5\end{array}$ & $\begin{array}{c}\mu E q . / \mathrm{ml} . \\
20 \\
30 \\
40\end{array}$ & $\begin{array}{l}2 \\
2 \\
2\end{array}$ & $\begin{array}{l}13.9 \\
20.8 \\
27.6\end{array}$ & $\begin{array}{l}13.8 \\
20.3 \\
26.9\end{array}$ & $\begin{array}{l}20.0 \\
26.6 \\
33.8\end{array}$ & $\begin{array}{l}12.6 \\
18.9 \\
24.9\end{array}$ & $\begin{array}{l}15.2 \\
22.3 \\
29.8\end{array}$ & $\begin{array}{l}4.8 \\
4.3 \\
4.0\end{array}$ & $\begin{array}{l}\text { uper./ml. } \\
3.7 \\
3.85 \\
4.45\end{array}$ & $\begin{array}{c}\mu E q . / \mu \text { per. } \\
1.30 \\
1.12 \\
0.90\end{array}$ \\
\hline \multirow[t]{2}{*}{5.0} & $\begin{array}{r}1 \\
2 \\
5 \\
10 \\
20 \\
30 \\
40 \\
60 \\
80 \\
140\end{array}$ & $\begin{array}{l}2 \\
2 \\
2 \\
2 \\
8 \\
2 \\
8 \\
4 \\
6 \\
2\end{array}$ & $\begin{array}{r}1.52 \\
2.14 \\
4.36 \\
7.32 \\
15.1 \\
21.3 \\
28.2 \\
41.3 \\
55.4 \\
94.7\end{array}$ & $\begin{array}{c}1.08 \\
1.88 \\
4.17 \\
7.53 \\
14.3 \\
21.0 \\
27.7 \\
40.7 \\
53.9 \\
94.0\end{array}$ & $\begin{array}{r}10.8 \\
14.2 \\
16.0 \\
18.6 \\
26.1 \\
32.0 \\
39.6 \\
52.5 \\
66.8 \\
104.8\end{array}$ & $\begin{array}{c}0.38 \\
0.75 \\
2.05 \\
4.77 \\
11.5 \\
18.2 \\
25.0 \\
37.6 \\
51.1 \\
90.4\end{array}$ & $\begin{array}{r}4.3 \\
5.4 \\
8.9 \\
11.6 \\
18.8 \\
24.6 \\
31.2 \\
44.7 \\
58.5 \\
98.5\end{array}$ & $\begin{array}{l}6.5 \\
8.8 \\
7.1 \\
7.0 \\
7.3 \\
7.4 \\
8.4 \\
7.8 \\
8.3 \\
6.3\end{array}$ & $\begin{array}{l}5.21 \\
6.72 \\
6.97 \\
6.91 \\
7.3 \\
6.9 \\
7.3 \\
7.45 \\
7.85 \\
7.2\end{array}$ & $\begin{array}{l}1.25 \\
1.31 \\
1.02 \\
1.01 \\
1.00 \\
1.07 \\
1.15 \\
1.05 \\
1.06 \\
0.88\end{array}$ \\
\hline & & & & & & & & \multicolumn{2}{|c|}{ Weighted average } & 1.08( \\
\hline
\end{tabular}


TABLE IV

Mean values for ion concentrations inside and outside the bag at several concentrations of calcium chloride and one of calcium chondroitin sulfate (period weight 570)

\begin{tabular}{|c|c|c|c|c|c|c|c|c|c|c|}
\hline 1 & 2 & 3 & 4 & 5 & 6 & 7 & 8 & 9 & 10 & 11 \\
\hline \multirow[b]{2}{*}{$\begin{array}{l}\text { Conc. } \\
\text { CaChS }\end{array}$} & \multirow[b]{2}{*}{$\begin{array}{l}\text { Conc. } \\
\mathrm{CaCl}_{2}\end{array}$} & \multirow{2}{*}{$\begin{array}{l}\text { No. of } \\
\text { experi- } \\
\text { ments }\end{array}$} & \multicolumn{6}{|c|}{ Conc. at equilibrium, $\mu E q$. per $m l$. } & \multirow[b]{2}{*}{ ChS- } & \multirow[b]{2}{*}{$\begin{array}{l}\text { Bound } \\
\mathbf{C}_{2++}^{++}\end{array}$} \\
\hline & & & $\mathrm{Ca}^{++} \mathrm{O}$ & $\mathrm{Cl}^{-} \mathrm{O}$ & $\mathrm{Ca}^{++1}$ & $\mathrm{Cl}-\mathbf{i}$ & $\begin{array}{l}\text { Free } \\
\mathrm{Ca}^{++} \mathbf{i}\end{array}$ & $\underset{\mathrm{Ca}^{++} \mathbf{B}}{\text { Bound }}$ & & \\
\hline \multirow[t]{2}{*}{$\begin{array}{c}\text { me. } / \mathrm{ml} . \\
5.0\end{array}$} & $\begin{array}{c}\mu E q . / \mathrm{ml} . \\
20 \\
40 \\
60 \\
80\end{array}$ & $\begin{array}{r}8 \\
7 \\
8 \\
10\end{array}$ & $\begin{array}{l}12.5 \\
23.4 \\
35.7 \\
46.2\end{array}$ & $\begin{array}{l}12.4 \\
23.8 \\
35.1 \\
46.9\end{array}$ & $\begin{array}{l}25.4 \\
37.0 \\
48.8 \\
62.0\end{array}$ & $\begin{array}{l}11.8 \\
22.8 \\
33.7 \\
45.7\end{array}$ & $\begin{array}{l}13.8 \\
25.8 \\
38.8 \\
48.6\end{array}$ & $\begin{array}{l}11.6 \\
11.5 \\
10.0 \\
13.4\end{array}$ & $\begin{array}{c}\text { mper./ml. } \\
6.8 \\
7.1 \\
7.55 \\
8.15\end{array}$ & $\begin{array}{c}\text { ERq./mper. } \\
1.71 \\
1.62 \\
1.32 \\
1.64\end{array}$ \\
\hline & & & & & & & \multicolumn{3}{|c|}{ Weighted average } & $1.58(n=33)$ \\
\hline
\end{tabular}

calculate the amount of sodium bound. The first assumption can be represented by the equation:

$$
\mathrm{Na}^{+} \mathrm{i} \text { free }+\mathrm{ChS}^{-} \rightleftarrows\left(\mathrm{Na}^{+} \mathrm{i} \text { bound } \cdot \mathrm{ChS}^{-}\right)
$$

The second assumption permits calculation of $\mathrm{Na}^{+} \mathbf{i}$ free from the Donnan relation:

$$
\mathrm{Na}^{+} \text {i free }=\frac{\mathrm{Na}^{+} \mathrm{o} \times \mathrm{Cl}^{-} \mathrm{o}}{\mathrm{Cl}^{-} \mathrm{i}}
$$

where $\mathrm{Na}+\mathrm{i}$ free is the concentration of unbound sodium in the inside solution, and $\mathrm{Na}^{+} \mathrm{o}, \mathrm{Cl}^{-} \mathrm{o}$, and $\mathrm{Cl}-\mathrm{i}$ are the concentrations of sodium and chloride outside and chloride inside, respectively (Columns 4,5 , and 7 ). Finally, since the analytically determined values of sodium in Column 6 represent the total sodium (bound plus free) inside the bag, the bound sodium may be calculated from the relation:

$$
\mathrm{Na}+\mathrm{i} \text { bound }=\mathrm{Na}+\mathrm{i} \text { total }-\mathrm{Na}+i \text { free }
$$

Column 8 of Table II gives the values of $\mathrm{Na}^{+} \mathrm{i}$ free calculated by equation (B), and Column 9 gives values of $\mathrm{Na}^{+} \mathrm{i}$ bound calculated by the use of equation $(C)$ both in $\mu \mathrm{Eq}$. per $\mathrm{ml}$.

In order to relate experiments done at various concentrations of chondroitin sulfate and at the same time to correct for the small changes in volume inside the bag due to shifts of water, the bound sodium inside the bag has been calculated per period of chondroitin sulfate by dividing the values of Column 9 by the periods per ml. of chondroitin sulfate. This figure is obtained from the relation:

$$
\mathrm{ChS}=1 / 2\left(\mathrm{Na}^{+} \mathrm{i}-\mathrm{Cl}-\mathrm{i}\right)
$$

Column 10 contains values of the concentration at equilibrium of chondroitin sulfate as $\mu$ periods per $\mathrm{ml}$, and Column 11 the values of $\mathrm{Na}^{+} \mathrm{i}$ bound as $\mu$ Eq. per $\mu$ period of chondroitin sulfate. At several different concentrations of both chondroitin sulfate and sodium chloride these values appear to be constant and to average 0.95 equivalent of sodium per period of chondroitin sulfate. This amounts to a 47 per cent neutralization of the charge the polyion would have if it were completely ionized.

Similarly, the data of Tables III and IV show that potassium and calcium ions are also bound. The binding of potassium seems to be slightly higher than that of sodium. Calcium binding, however, is higher, $1.6 \mu \mathrm{Eq}$. per $\mu$ period. This value for calcium represents 80 per cent neutralization of the charge the chondroitin sulfate would have if it were completely ionized.

There is evidence that chondroitin sulfate in cartilage exists as a component of a mucoprotein (11). For studies on the physiology of cartilage and probably of connective tissue, the binding of cations by the mucoprotein would be of more significance than the binding of cations by chondroitin sulfate. In Table $\mathrm{V}$ are data obtained by equilibrium dialysis of potassium chloride against the potassium salt of chondromucoprotein. Potassium binding seems to be slightly lower than occurs with chondroitin sulfate.

The analysis of the data presented is based on the assumption that the Donnan expression of the equilibrium is valid for the system studied if concentrations are used in the equation $(B)$. The equilibrium is more correctly expressed as a product of activities:

$$
\mathrm{aNa}^{+} \mathrm{i}=\frac{\mathrm{Na}^{+} \mathrm{o} \times \mathrm{Cl}^{-} \mathrm{o} \times \gamma^{2}}{\mathrm{Cl}^{-} \mathrm{i} \times \gamma^{\mathrm{i}}}
$$


In this equation ${ }^{2} \mathrm{Na}^{+} \mathrm{i}$ is the activity of sodium in the inside solution, $\gamma o$ is the activity coefficient of either the sodium or the chloride ion outside the bag, which is simply the value in sodium chloride solution (15). The activity coefficient of the chloride ion inside the bag, $\gamma \mathrm{i}$, is assumed to be the same as in sodium chloride solution since there is probably no interaction between the chloride ion and the chondroitin sulfate. Evidence that polyions do not affect the activity coefficients of by-ions (small ions of the same kind of charge as that of the polyion) has been discussed by Kagawa and Katsuura (16). Since the concentrations of $\mathrm{Cl}^{-}$ inside and outside the bag are nearly equal, $\gamma \mathrm{i}$ and $\gamma 0$ will be practically equal and the equation $(D)$ simplifies to $(E)$ :

$$
{ }^{a} \mathrm{Na}+\mathrm{i}=\frac{\mathrm{Na}^{+} \mathrm{O} \times \mathrm{Cl}^{-} \mathrm{O} \times \text { yo }}{\mathrm{Cl}^{-} \mathrm{i}}
$$

This gives a simple means to calculate the activity of the sodium ion inside the bag. Assuming the concentrations of sodium ion inside the bag are given by the values in Column 6 , Table II, it is now possible to calculate the activity coefficients of the sodium inside the bag, $\gamma \mathrm{Na}^{+} \mathrm{i}$, in the presence of chondroitin sulfate from the relation:

$$
\gamma \mathrm{Na}+\mathrm{i}=\frac{\mathrm{aNa}^{+} \mathrm{i}}{\mathrm{Na}^{+} \mathrm{i} \text { total }}
$$

Such calculations have been made for both sodium and potassium ions and the results are plotted as Curve $\mathrm{A}$ in Figure 2. This curve has an unusual shape, showing a very sharply decreasing activity coefficient as the concentration of sodium or potassium decreases from 0.03 toward $0.01 \mathrm{M}$. The more familiar simple alkali metal salts over this range show a different curve, with a rising activity coefficient which approaches a value of one as the concentration approaches zero (17). Curve $B$ of Figure 2 is such a curve. It is plotted through the circles which represent the activity coefficients of sodium or potassium ions in solutions of their chlorides at the concentrations represented by the abscissae (15).

It appears that there are two explanations for the results contained in Tables II, III, IV, and V. The first is that the activity coefficient of the cation inside the bag is depressed due to the presence of the polyion and leads to Curve A of Figure 2. The second is that some cations inside the bag are bound to the polyanion and lead to the calculated values of Columns 9 and 11 of Tables II to V. The first explanation is thermodynamically correct but gives no reason why activity coefficients should be progressively more depressed at lower salt concentrations. The second explanation suggests a mechanism for the depression of the activity coefficients. In fact, if the activity coeffcients are calculated using the free sodium ion inside the bag (Column 8, Table II) instead of the total sodium ion (Column 6, Table II), then the $\gamma$ Nai turns out to be close to that in simple $\mathrm{NaCl}$ solution as shown by using the following equation:

$$
\gamma \mathrm{Na}+\mathrm{i}=\frac{\mathrm{aNa}+\mathrm{i}}{\mathrm{Na}+\mathrm{i}-7.5}
$$

This simply expresses the proposition that the significant sodium ion concentration inside the bag is not $\mathrm{Na}^{+} \mathrm{i}$, the value of Column 6, Table II, which

TABLE V

\begin{tabular}{|c|c|c|c|c|c|c|c|c|c|c|}
\hline 1 & 2 & 3 & 4 & $\mathbf{5}$ & 6 & 7 & 8 & 9 & 10 & 11 \\
\hline \multirow[b]{2}{*}{$\underset{\mathbf{K}_{2} \mathbf{C M P}}{\text { Conc. }}$} & \multirow{2}{*}{$\underset{\text { start }}{\text { Conc. }}$} & \multirow{2}{*}{$\begin{array}{l}\text { No. of } \\
\text { experi- } \\
\text { ments }\end{array}$} & \multicolumn{6}{|c|}{ Conc. at equilibrium, $\mu E q$. per $m l}$. & \multirow[b]{2}{*}{ CMP- } & \multirow[b]{2}{*}{$\underset{K^{+} \mathbf{i}}{\text { Bound }}$} \\
\hline & & & $\mathbf{K}+\mathbf{O}$ & $\mathrm{Cl}^{-} \mathrm{O}$ & $\mathbf{K}+\mathbf{i}$ & $\mathbf{C l}-\mathbf{i}$ & $\begin{array}{c}\text { Free } \\
\mathbf{K}+\mathbf{i}\end{array}$ & $\underset{\mathbf{K}^{+} \mathbf{i}}{\text { Bound }}$ & & \\
\hline \multirow[t]{2}{*}{$\begin{array}{c}m s . / m l \\
5\end{array}$} & $\begin{array}{c}\boldsymbol{\mu E q} \cdot / \mathbf{m l} . \\
10 \\
20 \\
30 \\
40 \\
50 \\
60 \\
80\end{array}$ & $\begin{array}{r}4 \\
5 \\
2 \\
10 \\
2 \\
4 \\
5\end{array}$ & $\begin{array}{c}7.84 \\
14.4 \\
21.3 \\
27.7 \\
33.9 \\
40.9 \\
54.8\end{array}$ & $\begin{array}{l}7.56 \\
14.0 \\
21.1 \\
27.4 \\
33.1 \\
40.2 \\
53.1\end{array}$ & $\begin{array}{l}15.6 \\
22.9 \\
29.3 \\
36.0 \\
44.1 \\
48.9 \\
62.0\end{array}$ & $\begin{array}{c}5.82 \\
11.7 \\
18.0 \\
24.4 \\
29.6 \\
37.2 \\
50.2\end{array}$ & $\begin{array}{l}10.2 \\
17.2 \\
25.0 \\
30.5 \\
37.9 \\
44.2 \\
58.0\end{array}$ & $\begin{array}{l}5.4 \\
5.7 \\
4.3 \\
5.5 \\
6.2 \\
4.7 \\
4.0\end{array}$ & $\begin{array}{l}\text { mper./ml. } \\
4.89 \\
5.6 \\
5.65 \\
5.8 \\
7.25 \\
5.85 \\
5.9\end{array}$ & $\begin{array}{c}\text { Mq./mper. } \\
1.10 \\
1.02 \\
0.76 \\
0.95 \\
0.86 \\
0.80 \\
0.68\end{array}$ \\
\hline & & & & & & & & Wei & verage & $0.90(n=32)$ \\
\hline
\end{tabular}

Mean values for ion concentrations inside and outside the bag at several concentrations of potassium chloride and one of the potassium salt of chondromucoprotein (period weight 800) 
TABLE VI

Mean values for ion concentrations inside and outside the bag at several concentrations of potassium chloride and with methyl chondroitin (5 mg. per ml.) inside the bag

\begin{tabular}{|c|c|c|c|c|c|c|}
\hline \multirow{2}{*}{$\underset{\text { start }}{\text { Conc. }}$} & \multirow{2}{*}{$\begin{array}{l}\text { No. of } \\
\text { experi- } \\
\text { ments }\end{array}$} & \multicolumn{4}{|c|}{$\begin{array}{l}\text { Conc. at equilibrium, } \\
\mu E q . \text { per } m l \text {. }\end{array}$} & \multirow{2}{*}{$\frac{\mathrm{K}^{+} \times \times \mathrm{Cl}^{-}}{\mathrm{K}^{+} \mathbf{i} \times \mathrm{Cl}^{-1} \mathbf{i}}$} \\
\hline & & $\mathrm{K}^{+}$ & $\mathrm{Cl}^{-} \mathrm{o}$ & $\mathbf{K}^{+} \mathbf{i}$ & $\mathrm{Cl}-\mathrm{i}$ & \\
\hline $\begin{array}{c}\mu E q . / m l . \\
20 \\
40 \\
60 \\
80\end{array}$ & $\begin{array}{l}2 \\
2 \\
2 \\
2\end{array}$ & $\begin{array}{l}14.6 \\
28.0 \\
40.5 \\
54.1\end{array}$ & $\begin{array}{l}13.8 \\
26.3 \\
39.3 \\
53.2\end{array}$ & $\begin{array}{l}14.8 \\
28.2 \\
42.1 \\
54.4\end{array}$ & $\begin{array}{l}13.0 \\
25.9 \\
38.7 \\
52.1\end{array}$ & $\begin{array}{l}1.05 \\
1.01 \\
0.98 \\
1.02\end{array}$ \\
\hline
\end{tabular}

is the analyzed total concentration of $\mathrm{Na}^{+}$inside the bag, but this amount diminished by 7.5 , the average number of $\mu \mathrm{Eq}$. per $\mathrm{ml}$. bound to the chondroitin sulfate (the average of the last eight values of Column 9, Table II). Plotting these values of $\gamma \mathrm{Nai}$ against $\left(\mathrm{Na}^{+} \mathrm{i}-7.5\right)$, as well as the corresponding set from the data of Table III for potassium, gives the upper set of solid points of Figure 2, which rather closely follow Curve B except at the dilute end of the curve where errors are greatest. The closeness with which the upper set of solid points fits Curve $B$ over the whole range of concentration is a justification for the assumption that the amount of sodium or potassium ion bound is practically constant ( $7.5 \mu \mathrm{Eq}$. per ml.) over the range of these studies.

As a general check on the method and approach used to study the binding problem, an experiment was conducted with a derivative of chondroitin sulfate containing no ionic groups, the methyl ester of desulfated chondroitin sulfate. In this compound the carboxylate group is methylated and the ester sulfate group is replaced by a hydroxyl group (Figure 1). The results summarized in Table VI show that at equilibrium the potassium ion concentrations inside and outside the bag are equal, and the product of the potassium and chloride ion concentrations inside the bag is equal to the product of their concentrations in the outside solution. Not only is there no binding of cations by the methyl chondroitin but, since methyl chondroitin is a non-diffusible, non-charged particle, there is no Donnan effect either.

\section{DISCUSSION}

The data of this study are in general agreement with that of others who used different methods on synthetic polyelectrolytes. Huizenga, Grieger, and Wall (3), using solutions of sodium polyacrylate in transference cells, found that the polyelectrolyte bound sodium ions in amounts up to 60 per cent of the total sodium ions present. Wall and Doremus (4) found the fraction of sodium bound decreased with polymer concentration, that the extent of binding was independent of temperature in the range of $0^{\circ}$ to $42^{\circ} \mathrm{C}$., and that potassium seemed to be bound to the same extent as sodium. Applying the same method to sodium polyphosphate, they concluded counterions could be bound to the extent of 70 per cent (5). For the divalent cation, Wall and Eitel (6) found binding to partially neutralized polyacrylate occurred to the extent of 70 per cent. Oth and Doty (7), from conductance measurements, estimated the effective charge of the polyion of sodium polymethacrylate solutions to be 60 per cent of the total charge that the polyion would have if ionization were complete. The shapes of conductance-concentration curves for a synthetic polycationic salt led Fuoss (8) to conclude that binding of a considerable fraction of the counterions occurred at higher polyion concentration.

The above studies were not made on systems at equilibrium. Kagawa and Katsuura (9) did use an equilibrium system and measured silver ion activities in cells containing carboxymethylcellulose. They found silver ion activity coefficients "depressed to an extent never experienced in simple electrolyte solutions." At constant carboxymethylcellulose the silver ion activity coefficient decreased with decreasing concentration of silver in a concentration range where the reverse would have been expected. This is similar to the trend of Curve A, Figure 2.

Little can be stated concerning the specific nature of the binding of sodium, potassium, or calcium to chondroitin sulfate except that it renders part of the cations osmotically inactive. Two kinds of binding of counterions by polyelectrolytes have been considered $(18,19)$. In the first, the polyelectrolyte molecule in solution is thought to exist as a microvolume in which the polyion is coiled. This microvolume has a high charge density distinct from the adjacent solution from which the polyion is absent and it therefore attracts counterions. This microvolume is sometimes considered as a separate phase distinct from the rest 


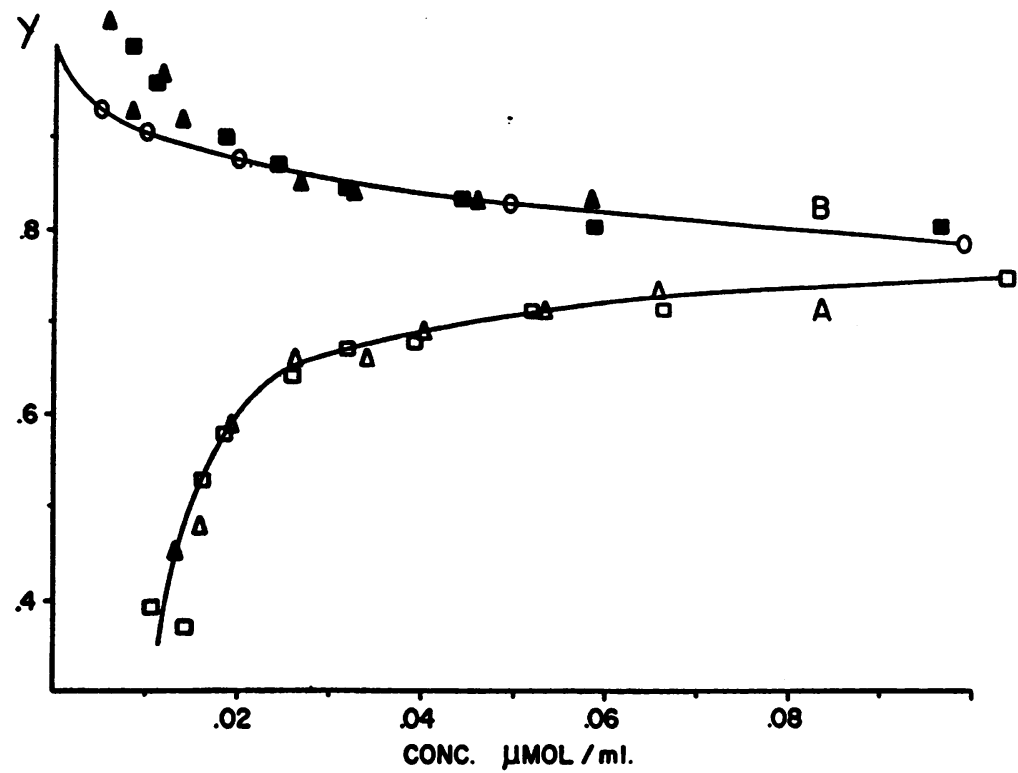

Fig. 2. Activity Coefficients of $\mathrm{NA}^{+}$OR $\mathrm{K}^{+}$Inside the Bag in the Presence of Chondroitin Sulfate

Curve $A$, values of points calculated from equation $(F) ; \Delta$ for $\mathrm{Na}^{+} ; \square$ for $\mathrm{K}^{+}$. Curve $B$, values of points calculated from equation $(G) ; \Delta$ for $\mathrm{Na}^{+}$; a for $\mathrm{K}^{+}$. The points represented by circles (O) are taken from data for $\mathrm{NaCl}$ or $\mathrm{KCl}$ given in Harned and Owen (15).

of the solution, and the counterions are not considered to be held in any particular charged sites of the polyion. The second view regards the binding of counterions by polyions to be the result of the formation of specific ion pairs, so a particular counterion is fixed at a particular charged site of the polyion. Either kind of binding would produce an apparent decrease in activity of the counterions.

Ion pairs have been studied for simple ions in media of low dielectric constant such as alcohols (20). Some evidence that ion pair formation can occur between the charged sites of chondroitin sulfate and certain polyvalent complex cobalt cations has been found based on an increase in the ultraviolet absorption of the hexamminecobaltic cation in the presence of chondroitin sulfate (21). In such a system added sodium or potassium chloride can decrease the binding of the complex cobalt cations to the chondroitin sulfate as shown by equilibrium dialysis. If this could be shown to be a competitive effect then it might follow that sodium or potassium ions are also bound to chondroitin sulfate as ion pairs.

The binding of counterions by a polyion in solu- tion is probably different from the ion association that occurs with insoluble ion-exchange resins. An ion-exchange resin is an insoluble polyelectrolyte which must associate an equivalent amount of counterions to maintain electrical neutrality. The state of ionization of the counterions in the insoluble phase of an ion-exchange resin has until recently not been considered (22). The behavior of cations in whole cartilage discussed by Boyd and Neuman (23) is of the ion-exchange type.

The binding of counterions by the anionic polysaccharides of connective tissue probably has physiological consequences. An interesting example is that studied by Joseph, Engel, and Catchpole in their attempt to measure the effect of hormones on the activities of sodium, potassium, and calcium ions in living connective tissues (24).

Increasing evidence has been presented to implicate connective tissue constituents as possibly storing osmotically inactive sodium in certain disease states in man and in experimentally produced conditions in animals (24-29). Tissues chiefly classified as connective tissue in type have been shown to participate in experimental conditions involv- 
ing sodium metabolism. The data presented in this study indicate that a component of connective tissue, chondromucoprotein and its polyelectrolyte constituent chondroitin sulfate, can bind $\mathrm{Na}^{+}$, and this property may play a role in the situations described.

\section{SUMMARY}

Equilibrium dialysis of sodium, potassium, or calcium chondroitin sulfate against varied concentrations of the corresponding sodium, potassium, or calcium chlorides has been studied. Assuming the validity of the Donnan relation, the results have been interpreted as due to a binding of part of the cation by the chondroitin sulfate polyanion and the amount of cation bound per period of chondroitin sulfate has been calculated. The results indicate that the amount of cation bound is constant over the concentration range studied, and is approximately 0.9 equivalent per period of chondroitin sulfate for sodium or potassium, and 1.3 equivalents per period for calcium. The mucoprotein of cartilage also bound 0.9 equivalent of potassium per period. Bound cation in the present discussion means osmotically inactive cation.

\section{REFERENCES}

1. Mathews, M. B., and Dorfman, A., The molecular weight and viscosity of chondroitin sulfuric acid. Arch. Biochem. \& Biophys., 1953, 42, 41.

2. Davidson, E. A., and Meyer, K., Structural studies on chondroitin sulfuric acid. II. The glucuronidic linkage. J. Am. Chem. Soc., 1955, 77, 4796.

3. Huizenga, J. R., Grieger, P. F., and Wall, F. T., Electrolytic properties of aqueous solutions of polyacrylic acid and sodium hydroxide. I. Transference experiments using radioactive sodium. J. Am. Chem. Soc., 1950, 72, 2636.

4. Wall, F. T., and Doremus, R. H., Electrolytic propperties of aqueous solutions of polymeric electrolytes. J. Am. Chem. Soc., 1954, 76, 1557.

5. Wall, F. T., and Doremus, R. H., Electrolytic transference properties of polyphosphates. J. Am. Chem. Soc., 1954, 76, 868.

6. Wall, F. T., and Eitel, M. J., Strontium ion association with partially neutralized polyacids. J. Am. Chem. Soc., 1957, 79, 1550.

7. Oth, A., and Doty, P., Macro-ions. II. Polymethacrylic acid. J. Phys. Chem., 1952, 56, 43.

8. Fuoss, R. M., Electrical transport by polyelectrolytes. J. Polymer. Sci., 1954, 12, 185.

9. Kagawa, I., and Katsuura, K., Activity of counterion in polyelectrolyte solutions. J. Polymer. Sci., 1955, $17,365$.
10. Einbinder, J., and Schubert, M., Crystallization of calcium chondroitin sulfate. J. Biol. Chem., 1951, 191, 591.

11. Shatton, J., and Schubert, M., Isolation of a mucoprotein from cartilage. J. Biol. Chem., 1954, 211, 565.

12. Kantor, T. G., and Schubert, M., A method for the desulfation of chondroitin sulfate. J. Am. Chem. Soc., 1957, 79, 152.

13. Berger, E. Y., Calcium determination in biologic material. Clin. Chem., 1955, 1, 249.

14. Strenger, T., and Asberg, E. G. M. T., Een snelle microchloorbepaling. Nederl. Tijdschr. Geneesk., 1953, 97, 2018.

15. Harned, H. S., and Owen, B. B., Physical Chemistry of Electrolyte Solutions. New York, Reinhold Publishing Corporation, 1943, pp. 557 and 558.

16. Kagawa, I., and Katsuura, K., Activity coefficient of byions and ionic strength of polyelectrolyte solutions. J. Polymer. Sci., 1952, 9, 405.

17. Glasstone, S., Textbook of Physical Chemistry. New York, D. Van Nostrand Company, Inc., 1946, pp. 954-968.

18. Osawa, F., Imai, N., and Kagawa, I., Theory of strong polyelectrolyte solutions. I. Coiled macro ions. J. Polymer. Sci., 1954, 13, 93.

19. Harris, F. E., and Rice, S. A., A chain model for polyelectrolytes. I. J. Phys. Chem., 1954, 58, 725.

20. Robinson, R. A., and Stokes, R. H., Electrolyte Solutions. London, Butterworths Scientific Publications, 1955, pp. 381-413.

21. Vouras, M., and Schubert, M., The outer sphere association of chondroitin sulfate with polyvalent complex cations. J. Am. Chem. Soc., 1957, 79, 792.

22. Gregor, H. P., Ion-pair formation in ion exchange systems. J. Am. Chem. Soc., 1951, 73, 3537.

23. Boyd, E. S., and Neuman, W. F., The surface chemistry of bone. V. The ion-binding properties of cartilage. J. Biol. Chem., 1951, 193, 243.

24. Joseph, N. R., Engel, M. B., and Catchpole, H. R., Homeostasis of connective tissues. II. Potassiumsodium equilibrium. Arch. Path., 1954, 58, 40.

25. Farber, S. J., and Soberman, R. J., Total body water and total exchangeable sodium in edematous states due to cardiac, renal or hepatic disease. J. Clin. Invest., 1956, 35, 779.

26. Silver, L., Christie, R. W., and Dahl, L. K., Connective tissue as a major sodium reservoir. Federation Proc., 1957, 16, 372.

27. Bergstrom, W. H., The participation of bone in total body sodium metabolism in the rat. J. Clin. Invest., 1955, 34, 997.

28. Levitt, M. F., Turner, L. B., Sweet, A. Y., and Pandiri, D., The response of bone, connective tissue, and muscle to acute acidosis. J. Clin. Invest., 1956, 35, 98.

29. Woodbury, D. M., Effect of acute hyponatremia on distribution of water and electrolytes in various tissues of the rat. Am. J. Physiol., 1956, 185, 281. 